\title{
CALEI- Geometría y topogénesis en la 15 arquitectura religiosa del nororiente de la Nueva Galicia
}

M. ALEJANDRO SIFUENTES SOLÍS

Departamento de Teoría y Método/UAA masifuentes@correo.uaa.mx

\section{Advertencia}

Este texto es un subproducto del estudio riguroso de la portada de la capilla de una hacienda del período novohispano, ubicada en la antigua frontera nororiental de la Nueva Galicia. La investigación histórica que acompañó al análisis arquitectónico, realizada entre 1991-92, ${ }^{1}$ tuvo en su origen al materialismo histórico-dialéctico como trasfondo teórico. He decidido respetar dicho enfoque por una razón fundamental: aunque admito que causa escozor entre los académicos, que es limitado (como todo "modelo", enteramente perfectible), para explicar e interpretar la realidad social y que existen nuevos enfoques, como la historia cultural, para aprehender las realidades que designa, no juzgué pertinente forzar los resultados -y no faltará quién diga, sin que le falte razón, que de eso peca precisamente este trabajo- dentro de un nuevo entramado conceptual.

\footnotetext{
El estudio completo fue originalmente elaborado para presentarlo como tesis de licenciatura en arquitectura en 1993, siendo revisado, ampliado y corregido en 2002 para su edición como libro (La portada del templo de San Nicolás de Quijas. Arquitectura religiosa de las haciendas del semidesierto pinense, de próxima aparición). Algunos capítulos fueron publicados previamente, con diversas modificaciones, en el número 15 de la revista Investigación y Ciencia de la UAA (1995); en los números 1, 2 y 3 del Boletín del Centro Tecnológico de la UAA (1994-95); y en el Anuario de Ciencias Sociales (año 2, tomo I, UAA, 1996). Esta entrega contiene algunas ideas, argumentos y evidencias no publicados con anterioridad.
}
C
A $\quad L \quad E$
E I
D
O S
C
O
(5) 
Parto también de la idea de que, como lo ha expresado acertadamente Guillermo Tovar de Teresa, el mundo puede abrirse desde un vértice -en este caso, la portada del templo y comprenderse desde un átomo. ${ }^{2}$ Desde esta perspectiva, intento construir una explicación congruente con la evidencia tangible del monumento analizado y, al mismo tiempo, abrir vías de explicación e interpretación más generales respecto a algunos de los procesos de producción de la arquitectura religiosa del corredor que unía los minerales de San Luis Potosí y Zacatecas, en el nororiente de la Nueva Galicia, insertando los argumentos en una discusión que desearía ampliar incluso hasta la concepción misma de los recintos de culto novohispanos de los siglos XVII y XVIII. En este sentido, la tesis central que defiendo, en orden a esa explicación o interpretación general, es que bajo el ropaje barroco y el fuerte simbolismo cristiano de la arquitectura religiosa novohispana, incluso con independencia de sus modalidades regionales y su diversidad estilística, subsiste un sistema de proporciones matemáticas muy precisas que vinculan a la geometría pitagórica, la cosmología platónica y el misticismo agustiniano (en una suerte de teoría implícita de la proporción arquitectónica) con el pensamiento escolástico de los siglos XVII y XVIII (aristotélico- tomista), y ambos con las condiciones de producción material de los recintos de culto.

Este texto se organiza en seis apartados. En los dos primeros expongo algunos aspectos históricos del contexto territorial y de la hacienda en la que se ubica el pequeño templo dedicado a San Nicolás de Tolentino, cuyo examen arquitectónico e iconográfico hago en el tercer apartado. En el cuarto, que constituyó el objeto central de la investigación, expongo los resultados del análisis armónico de la portada del recinto para, a partir de ellos, discutir en el quinto el rol de

Ver el Prólogo del libro de M. Alejandro Sifuentes Solís, José Luis García Rubalcava y Miguel R. Martín del Campo B. Medina, El Camarín de San Diego y su geometría simbólica, Aguascalientes, Universidad Autónoma de Aguascalientes, 1998, p. 14. Mauricio Beuchot se hace eco de esta consideración al afirmar que "...la comprensión se da cuando lo particular embona en lo universal que lo contiene, y allí cobra sentido"; ver la edición electrónica "Perfiles esenciales de la hermenéutica: Hermenéutica analógica", en "http://ensayo.rom.uga.edu/critica/teoria/beuchot". 
las portadas de los templos y capillas no monumentales de la región de Pinos, sus alcances e implicaciones en el contexto más amplio de la sociedad novohispana y en el ancho cuadro de los valores sancionados por la ideología religiosa vigente en ese período que permitieron concebir una arquitectura cargada de un simbolismo religioso regulado por una estructura geométrico-matemática rigurosa. Finalmente, el sexto y último apartado intenta tejer una explicación coherente del objeto de estudio, insertándola en una digresión epistemo metodológica consecuente con una interpretación histórico-dialéctica de la sociedad.

\section{Breve apunte fistórico}

El actual municipio de Pinos, Zacatecas, localizado al sureste del estado, se ubica geográfica y climatológicamente en el desierto potosino, dentro del área conocida en el virreinato como el "Gran Tunal", en territorio chichimeca, cuya extensión, según Elías Amador, comprendía "...desde Comanja, estado de Guanajuato, hasta Pinos y posiblemente hasta Aguascalientes y El Teúl". ${ }^{3}$

Pinos es un lugar particularmente frío en invierno y caluroso el resto del año; es un territorio poblado por magueyes, palmas, yucas, nopaleras, órganos, biznagas y toda clase de flora propia de las regiones desérticas; coyotes, liebres y serpientes son parte de la fauna local; se padece una crónica escasez de agua, por lo que el abastecimiento se consigue frecuentemente en los famosos "ojitos" de agua. En tiempos muy remotos, miles de millones de años, el mar debió haber cubierto la región, a juzgar por la gran cantidad de fósiles marinos que se han encontrado y, tal vez cientos de años atrás, bosques de pinos habrían tapizado los cerros circundantes, derivando posiblemente de ahí el nombre con el que se le conocía: "Sierra de Pinos".

Las actividades económicas, esencialmente la agricultura y la ganadería, dependen de los ciclos pluviales, mientras que la minería,

Citado por Margarita Hoffner Long en Elementos para una interpretación de la Historia de Zacatecas. Siglos XVI al XIX, Zacatecas, Universidad Autónoma de Zacatecas, 1988, p. 38 . 
otrora la fuente de la riqueza regional, ha venido considerablemente a menos; del mismo modo, la producción y venta de mezcal, cuya fama ha hecho trascender el nombre de Pinos, ha disminuido visiblemente su ritmo. Toda la región se levanta sobre los 2000 metros por encima del nivel del mar, destacando el Cerro de la Gallina, que alcanza los 3091 metros de altitud, ${ }^{4}$ a cuyas faldas se erigió una singular villa con el nombre original de Nuestra Señora de la Concepción de Sierra de Pinos.

La zona fue rica en acontecimientos históricos que, indiscutiblemente, quedaron marcados por sus ligas con procesos determinantes de la sociedad novohispana, a partir del descubrimiento e impulso de la producción minera en el norte. Como es sabido, el actual estado de Zacatecas formó una de las jurisdicciones del reino de la Nueva Galicia hasta los primeros años del siglo XVIII. En 1736 se convirtió en provincia, contando con un corregimiento en la capital minera y varias alcaldías mayores, una de las cuales fue precisamente la de Sierra de Pinos, territorio señalado además por el hecho de cruzar por él parte de la famosa ruta de la plata, escenario de cruentos episodios de la Guerra Chichimeca, siendo prácticamente frontera hacia el norte entre Nueva Galicia y el Nuevo Reino de León.

Cuando fue pacificada la frontera chichimeca, los españoles comenzaron a organizar la vida económica, política y social de la región en su propio provecho. Así, con el auge de las minas, Zacatecas se convirtió en un punto importante de la economía novohispana, a raíz de lo cual poco a poco se fue formando una clase dominante con amplia expresión en la minería, el comercio y desde luego en las haciendas; dicha clase estaba conformada por ganaderos, agricultores y mineros. Siguiendo a Hoffner, Zacatecas vio nacer de este modo un tipo de productor con capacidad para ejercer el poder político y el económico gracias a que no había comunidades indígenas que reclamaran para sí la tierra y gracias también al relativo aislamiento respecto a la capital del virreinato. Según esta autora, en la segunda mitad del siglo XVI, los mineros acumularon tierras por la vía de la mercedación real, por la compraventa o por simple ocupación de baldíos.

Ricardo Acosta Gómez, Miscelánea Histórica Pinense, San Luis Potosí, Biblioteca de Historia Potosina (Serie Cuadernos; 88), 1986, p. 70. 
La fuente incluso opina que en la constitución del Estado colonial, en la región, tuvieron participación directa productores con intereses locales, a diferencia del resto del territorio. ${ }^{5}$ Los hacendados, según la autora, alcanzaron "un elevado grado de influencia social" en el siglo XVII, destacándose varias familias de renombre. ${ }^{6}$

De entre las haciendas -y sus propietarios- más importantes en Zacatecas, Benjamín Rocha señala la hacienda de San Nicolás de la familia de los Quijas Escalante, ubicada precisamente en la frontera nororiental, en el confín del territorio neogallego, ${ }^{7}$ en la alcaldía mayor de Sierra de Pinos. ${ }^{8}$

\section{La hacienda de San Nicolás de los Quijas Escalante}

A la entrada del camino de terracería que venía de El Obraje, comunidad que a su vez se comunica hoy con la carretera que va a la ciudad de Pinos, entre el verdor seco de la flora semidesértica, característica de la región, y el azul grisáceo de las faldas de las mesas de San Nicolás, cuyo cerro del Chiquihuite le sirve de fondo, se divisa el casco de la antigua hacienda de San Nicolás de los Quijas Escalante, señalado visualmente en el paisaje por la elevación de su torre y por su graciosa cúpula. El casco se ubica, pues, a la entrada de El Nigromante, como hoy se le conoce al lugar de la antigua hacienda, a mano izquierda de lo que viene a ser la calle principal del poblado, entre cuyas gentes sobreviven remotos recuerdos de los Quijas y diversos apellidos relacionados.

A la fecha todavía son fragmentarias las noticias sobre la familia de los Quijas Escalante; ${ }^{9}$ los documentos probablemente estén dispersos

\footnotetext{
Hoffner, op. cit., pp. 56-61.

Ibid., pp. 85-86 y particularmente p. 87 .

Ver Gobierno del Estado de Zacatecas, La Ciudad de Zacatecas, $1^{\text {a }}$ reimpresión, Grupo Azabache, s. 1., 1992, p. 123.

8 Cfr. Ricardo Acosta Gómez, El Real de Sierra de Pinos. Efemérides Históricas, San Luis Potosí, Biblioteca de Historia Potosina (Serie Cuadernos 61), 1978.

9 Pueden encontrarse nuevas informaciones de Don Pedro y su descendencia en Sergio Javier Alfaro Aguirre, "La arquitectura de las haciendas agrícolas, ganaderas y mezcaleras de la alcaldía mayor de San Matías de la Sierra de Pinos. Siglo XVII",
} 
en buen número de archivos parroquiales, notariales, municipales o particulares, en varios estados de la república y es posible que hasta en los archivos españoles.

Ricardo Acosta afirma que el capitán Pedro de Quijas Escalante fue originario de la villa de Laredo, en el reino de Castilla, y que fue hijo legítimo del capitán Pedro Fernández de Quijas y de Doña María de Escalante y Boroto. Pedro hijo casó con doña Catalina de Saldaña, hija legítima de Antonio de Alcaraz y de Leonor de Saldaña, vecinos de Zacatecas. ${ }^{10}$ Tuvieron una descendencia numerosa (trece hijos vivos). ${ }^{11}$

No he encontrado referencia alguna de cuándo y cómo llegó Pedro de Quijas a la Nueva España. ${ }^{12}$ Tengo que partir del hecho de que hacia 1635-1638 se le ubica ya en la hacienda llamada San José Agua del Lobo, de la que fue, según Ricardo Acosta, su "primer propietario [...] quien pudo haberla adquirido por compra o por alguna merced de tierras concedida por el rey de España". ${ }^{13}$

tesis de maestría, Universidad Autónoma de Zacatecas, ca. 1998; Aurelio de los Reyes, ¿No queda huella ni memoria? (Semblanza iconográfica de una familia), México, IIEUNAM/El Colegio de México, 2002. Ricardo Acosta Gómez, Nueva miscelánea histórica de Pinos, San Luis Potosí, Gobierno del Estado de Zacatecas-Instituto Zacatecano de Cultura-SEC-Ayuntamiento de Pinos Centro Cultural Ricardo Acosta Gómez, 1999.

Acosta Gómez, El real..., op. cit., pp. 25-26.

Acosta Gómez, Miscelánea..., op cit., pp. 51-52.

12 Aurelio de los Reyes, apoyado en documentos antiguos que obran en el archivo particular de la familia Nieto García Rojas, afirma que desde 1620 Don Pedro se asentó en la cañada del Lobo; ver su obra citada, nota a pie de página, p. 95.

Acosta Gómez, Miscelánea..., op.cit., p. 41. El profesor Roberto Rodríguez, cronista de Loreto, Zac., afirma en cambio que el primer propietario fue el propio padre de Pedro, el también Capitán Pedro Fernández de Quijas; Cfr. Monografía del Municipio de Loreto, Zac., disponible en "http://www.geocities.com/loreto95/preambulo.html". A. de los Reyes cuestiona que a estas propiedades se les denominara "haciendas" en una fecha tan temprana, y que se trataría más bien de estancias que sólo adquirirían aquel estatus cuando se construyeron sus cascos respectivos; op. cit., p. 98. Alfaro Aguirre parece aceptar la primera denominación ya para 1619, cuando afirma que en el Primer Libro de Bautizos del Archivo Parroquial de Pinos (años 1619 a 1643, f.4) se hace mención de San Nicolás como hacienda; Cfr. "La arquitectura...", op.cit., p. 129. 
Lo anterior no suena descabellado, toda vez que hay cuando menos dos razones para creerlo: primero, basta recordar que la bonanza de minas atraía a los españoles como abejas a un panal y también que los soldados venidos a Nueva España no venían precisamente a hacer vida contemplativa; tómese en cuenta que el "primer gran florecimiento" de las minas de Zacatecas ocurrió entre 1610 y $1625,{ }^{14}$ por lo que no resultaba nada extraño ver a una gran cantidad de gambusinos, soldados y aventureros en la región en busca de nuevas vetas o bandoleros a someter (y no es improbable que éste fuera el caso de Pedro); segundo, para esos años la paz ya había sido alcanzada y podíase por lo tanto poblar y transitar la comarca sin temor alguno de sufrir reclamos indígenas de tierras, aunque la zona distaba de ser enteramente segura debido a las bandas de salteadores.

Es muy probable que las propiedades formadas dentro de la alcaldía mayor de Sierra de Pinos fueran obtenidas tal como lo sugiere la profesora Hoffner, es decir, la mercedación o la ocupación de baldíos para la constitución de estancias y sitios de ganado, o para tierras de labor. Exceptuando las haciendas de beneficio de metales, ¿se trataba de haciendas de subsistencia con carácter señorial? No lo sé, aunque las características de la región -esto es, el semidesierto, en el que la agricultura difícilmente podía prosperar- parecieran apuntar hacia esa línea de interpretación que solamente la investigación puede corroborar.

Una tercera razón puede invocarse: no es improbable que en el contexto del "mercado del matrimonio", 15 Pedro se haya casado con una doncella (doña Catalina de Saldaña) ya nacida en la Nueva España; en todo caso, documentos antiguos la mencionan como hija de un matrimonio "vecino de Zacatecas", lo que debió pesar lo suficiente en su ánimo como para pensar en establecerse y

Hoffner, op. cit., pp. 48-49.

Para una explicación detallada del "mercado del matrimonio" en la Nueva España, ver: David A. Brading, Mineros y Comerciantes en el México Borbónico (1763-1810), México, FCE, 1985, pp. 39-284. 
sentar cabeza en la comarca. Es casi seguro que sus hijos eran "españoles novohispanos": $!^{16}$ si no todos, hay noticia documental de que al menos dos de ellos nacieron precisamente en territorio de la alcaldía mayor de Sierra de Pinos como lo señalo más adelante.

En alguna de estas situaciones debió encajar nuestro personaje, puesto que los documentos que lo ubican en la región datan de una época en donde todavía la corona hacía cesiones reales. Gisela von Wobeser señala que el principal período de cesiones en el centro de la Nueva España comprendió los años de 1540 a 1620, repartiéndose en adelante en forma aislada; agrega que se otorgaron algunas en el siglo XVII en zonas poco pobladas. ${ }^{17}$ Es probable que para 1620 Pedro de Quijas se encontrara ya en la región zacatecana, ciertamente poco poblada. Cualquiera que haya sido el caso, lo cierto es que tenemos como hecho evidente que la familia Quijas Escalante comenzó a formarse a partir de su "solar" novohispano en la añeja hacienda del Lobo, encajonada en una inhóspita y poco accesible serranía, entre cañones otrora asolados por fieros guachichiles. Existen documentos que sugieren que, por lo menos, un tiempo los Quijas no fueron

16 Tanto en el Archivo Parroquial de Pinos (APP) como en el Fondo de Protocolos Notariales (FPN) del Archivo Histórico del Estado de Aguascalientes (AHEA) y en el Archivo Municipal del mismo estado (AMA) existen documentos que mencionan a varios hijos de Pedro de Quijas y sus descendientes. Por ejemplo de María, en el AMA: (1838, caja 2, f. 173-173), (1838, caja 2, f.174-175-176), (1838, caja 2, 1. 4, f. 74-75), (1838, caja 2, 1. 4, f. 164-165), (1838, caja 2, 1. 4, f. 71-72), (1838, caja 2, 1. 4, f.77-78), (1838, caja 2, 1. 4, f. 69-70), (1838, caja 2, 1. 4, f. 91-94), (1838, caja 2, f. 203v - $204-205 v-207-210),(1838$, caja 2, 1. 4, f. 85-86), (1838, f. 198v - 200). De Diego, en el AMA: (1838, caja 2, 1. 4, f. 11 15). De Nicolás y de Diego, en el AMA: (1838, caja 2, 1. 4, f. 83-85), (1838, caja 2, 1. 4, f. 104-112). Más información sobre Nicolás puede encontrarse en un documento del año 1687, una carta poder, en la que éste, consignado como vecino de la jurisdicción de Sierra de Pinos, se refiere a su vez al comisario Diego de Quixas Escalante, "vecino que fue de esta villa [Aguascalientes] clérigo presbítero ya difunto...", a quien menciona como "... mi hermano". El documento en AHEA, FPN, caja 80, exp. 6, esc. 16, f. $34 \mathrm{f}-37 \mathrm{v}$. Agradezco a Luis Gerardo Cortés por ponerme en la pista de esa carta poder y por haberme ayudado a resolver una duda sobre Nicolás.

17 Ver Gisela von Wobeser, La formación de la hacienda en la época colonial, México, IEEUNAM, 1983, pp. 19, 55 y ss. 
hacendados ausentistas, ya que tres partidas -dos de bautizo y otra de matrimonio- informan de su presencia en el lugar. ${ }^{18}$

Por razones que desconozco, otro de los hijos de Pedro, el también capitán Joseph de Quijas Escalante y Saldaña, aparece como dueño de la hacienda de San Nicolás, ${ }^{19}$ un lugar muy cercano a la hacienda del Lobo. San Nicolás era un lugar igualmente inhóspito y alejado, ubicado en las faldas de las que luego serían conocidas como "las mesas de San Nicolás", y ciertamente muy cercano al sitio de La Goleta, el lugar que se había señalado para fundar la villa Nueva de Toledo. Es probable que a raíz de la frustrada fundación de este asentamiento muchos peninsulares y españoles novohispanos abundaran y se establecieran por la comarca; no sé aún en qué momento se trasladó José de Quijas a la zona; lo que sí sé, en cambio, es que ni su padre ni él aparecen entre los pobladores que en 1603 vinieron a fundar la villa de Toledo, que quedaba muy cerca de la hacienda de San Nicolás, en los "llanos, montes y mesas de La Goleta", a escasos tres kilómetros, lo que sin embargo, admito, no es prueba concluyente de la imposibilidad de su presencia en la zona.

Se puede intentar reconstruir algún retazo de historia con algunos datos parciales sobre la fundación de la hacienda de San Nicolás, aunque nuevamente no puedo sino conjeturar al respecto. Es probable

18 Se trata de las partidas: 1) de Diego de Quijas, fundador del Convento de Religiosos de San Juan de Dios en Aguascalientes y Comisario del Santo Oficio de la Inquisición, propietario asimismo de la hacienda de San Nicolás Chapultepeque, también en Aguascalientes, que fue bautizado en la capilla de la Hacienda del Lobo en 1640 (ver RAG, Miscelánea..., op. cit., p. 50); 2) de fray Jacinto de Quijas, criollo y "varón muy ajustado a su apostólica regla", quien fue bautizado también en la capilla de la hacienda en el año de 1643 (RAG, El Real..., op. cit., p. 23), y quien habría nacido hacia 1635; y 3) de doña Felipa de Quijas Escalante, quien casó en El Lobo con el Capitán Rodrigo Morquecho, en el año de 1680 (Acosta Gómez, Miscelánea..., op. cit., p. 41).

Alfaro Aguirre supone que la propiedad pasó a manos de José de Quijas, que era el segundo de los hijos de Don Pedro, para evitar que la Hacienda se quedara en manos de la Iglesia en caso de que aquélla fuera heredada a Don Juan de Quijas, el primogénito, quien a su vez era sacerdote. Ver su obra citada "La arquitectura de las haciendas...", p. 130. A. de los Reyes informa que en una protocolización llevada a cabo en Fresnillo, Zac., se asienta que Don Pedro heredó indivisas El Lobo y San Nicolás a sus hijos Felipa y José, respectivamente; op. cit., p. 96. 
que la constitución de esta propiedad haya partido de alguna cesión real obtenida ya sea por merced, por compra, por herencia -lo cual sólo era posible como "censo enfitéutico",$-{ }^{20}$ o la simple ocupación de baldíos. ${ }^{21}$ De la existencia de estancias ganaderas y de caballerías en la zona da testimonio un plano de 1791, existente en el Archivo General de la Nación, en donde se pueden observar cuatro sitios de ganado mayor de los $38^{22}$ que pertenecían a la hacienda de San Nicolás, 19 y medio de los cuales, más 6 caballerías y 3/4, eran realengos pero anexados ilegalmente. ${ }^{23}$ Era bastante frecuente entre los hacendados anexarse tierras realengas que luego se procedía a regularizar mediante las composiciones, las que dieron inicio hacia mediados del siglo XVII. ${ }^{24}$ Tal fue el caso de la hacienda de San Nicolás, de la que se llevó a cabo una medición en 1759 con motivo de la regularización de tierras realengas, de las que su propietaria en ese entonces, doña Ana María del Río Tirado -esposa de Antonio Anselmo de Quijas Escalante, a su vez, hijo de José de Quijas Escalante y Floresno tenía escrituras, por lo que tuvo que pagar "doscientos pesos y el impuesto de media anata". ${ }^{25} \mathrm{Si}$ se considera que en el siglo XVI sólo se concedía a una persona uno o dos sitios de ganado y hasta cuatro caballerías, y que en el siglo XVII sólo se repartieron en forma aislada, ${ }^{26}$

20 El censo enfitéutico sólo daba el derecho, al que había obtenido el bien (el censuario), sobre la posesión útil de la propiedad, no sobre la posesión real, que permanecía en manos del que la había otorgado mediante censo (el censualista). Ver a este respecto von Wobeser, op. cit., p. 58. Alfaro Aguirre supone que las tierras de la Hacienda de San Nicolás habrían sido adquiridas por merced real a principios del siglo XVII, op: cit., p. 129.

El profesor Rodríguez, citado, sugiere un posible desmembramiento de una parte de las tierras de la Hacienda del Lobo, gracias al cual Don José habría obtenido la propiedad de la Hacienda de San Nicolás; Cfr. la dirección electrónica citada. Aproximadamente unas 67,000 hectáreas, lo que colocaba a esta hacienda en el rango de las mayores de la región.

23 Von Wobeser, op. cit., p. 152.

24 Ibid., p. 28 y ss., aunque la misma autora más adelante indica que los primeros ordenamientos sobre Composiciones datan de 1591; ver particularmente la p. 59. Ibid., p. 202. El impuesto de media anata era el "salario de seis meses que se pagaba como impuesto durante el primer año en que se ocupaba un cargo público", cfr. Brading, op. cit., p. 13.

26 Von Wobeser, op. cit., pp. 19-21 
podemos con ello darnos una idea aproximada de la importancia y la extensión de las tierras de San Nicolás, aun cuando no pueda estar en condiciones de afirmar qué parte de ellas era inculta.

Es probable que el núcleo principal de la hacienda pueda datarse hacia 1650 o antes, aunque quizá no como ahora lo conocemos. Von Wobeser afirma que el casco de San Nicolás, de planta cuadrangular, con un patio al centro, corresponde a una arquitectura que fue común en el siglo XVIII, ${ }^{27}$ pero una partida de entierros, la del primer propietario, el capitán José de Quijas Escalante y Saldaña, hijo de Pedro de Quijas Escalante y Boroto -muerto éste poco después de 1669, fecha en que otorgó su testamento en su hacienda del Lobo- ${ }^{28}$ prueba que el dicho casco, y quizá una modesta capilla, existía ya hacia 1677, fecha en que murió José. ${ }^{29}$ Aunque la partida citada no hace referencia a capilla alguna, era costumbre que los hacendados fuesen sepultados en ellas.

Para los primeros años del siglo XVIII debió consolidarse la propiedad al pasar a manos del hijo de aquél, José de Quijas Escalante y Flores, muerto y enterrado en 1710 en la capilla de su hacienda..$^{30}$ Una pequeña edificación y su torre de aspecto muy vetusto, que limita por el sur el patio del casco, y adosada por tanto al muro norte del templo del siglo XVIII, corresponde a la anterior descripción, la que es a su vez reforzada por von Wobeser, quien afirma que la iglesia "...estaba integrada dentro del conjunto ly que la cruz atriall se levantaba en el patio central", ${ }^{31}$ mientras que el templo del que aquí nos ocupamos es contiguo al casco y con acceso independiente desde el exterior, lo que sugiere su posteridad como lo refiero más adelante; el estado de deterioro de la pequeña capilla, evidentemente más pronunciado, sus características arquitectónicas y su aspecto ajado por lo años, delatan sin duda una mayor antigüedad.

\footnotetext{
Ibid., p. 202.

Acosta Gómez, Miscelánea..., op. cit., p. 51.

Acosta Gómez, Los Templos de Sierra de Pinos, Zac. y sus ministros, San Luis Potosí, Biblioteca de Historia Potosina (Serie Cuadernos 81), 1984, p. 18. A. de los Reyes documenta el bautizo de José en San Nicolás en 1657, y añade que el casco, según una piedra extraviada, se concluyó en 1697; op. cit., p. 97.

Acosta Gómez, Los Templos..., op. cit., p. 23.

Von Wobeser, op. cit., p. 202 (cursivas mías).
}

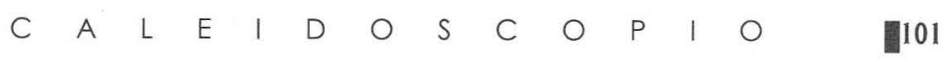




\section{El templo de la Hacienda de San Nicolás de Quijas}

El casco tenía una disposición tal que la fachada principal de la casa grande daba prácticamente al oriente, dominando una vista tan amplia del paisaje, que en el extremo izquierdo del arco visual, es decir, hacia el noreste, se divisaba en la lejanía la mancha blanquecina del caserío de Pinos, al pie de la impresionante mole rocosa del cerro de la Gallina, inevitable elemento de identificación visual del antiguo mineral. El conjunto tenía una forma de cuadrilongo: estaba organizado por un patio enorme con una noria al centro y rodeado con arcadas, cuyas paredes de fondo estaban decoradas con vistosas franjas verticales muy propias del fasto en que solían vivir los ricos hacendados de entonces; completaban el casco la "casa de morada" propiamente y diversas dependencias, tales como las trojes, bodegas y caballerizas, molino, etcétera. Mirando de frente la fachada, al lado de la izquierda, se localizaba el templo, que quedaba adosado al complejo y con relativa autonomía respecto a éste, lo que permitía al pueblo asistir a los oficios religiosos sin perturbar la vida privada de los hacendados, pero sin impedir a éstos participar en dichos oficios, gracias a una conveniente disposición de los espacios que comunicaban el recinto con el resto de las habitaciones. La iglesia tenía también su propio atrio -y lo conserva, si bien con una restauración discutible de su barda-, lo que contribuía a facilitar las procesiones y fiestas religiosas populares.

El templo está dedicado a San Nicolás de Tolentino, abogado de los penitentes; es una construcción en forma de cruz latina rematada en el crucero por una cúpula octagonal coronada con una linternilla, levantada sobre un tambor también octagonal. Consta de una sola nave dividida en tres tramos, de los cuales el del ingreso, de menores dimensiones, corresponde al coro, ubicado en el entrepiso; el presbiterio aloja un altar neoclásico, con toda seguridad posterior. La techumbre de la nave es a base de bóvedas de cañón corrido.

Adosada al muro norte, con ingreso actualmente sólo desde la nave, está la capilla que hasta hace relativamente poco tiempo fungió como bautisterio y que tiene una pequeña torrecilla de dos cuerpos con arcos conopiales, conjunto que es la antigua construcción que mencionan los documentos; posiblemente en ella estén enterrados los restos de dos de los hermanos Quijas Escalante, además de dos 


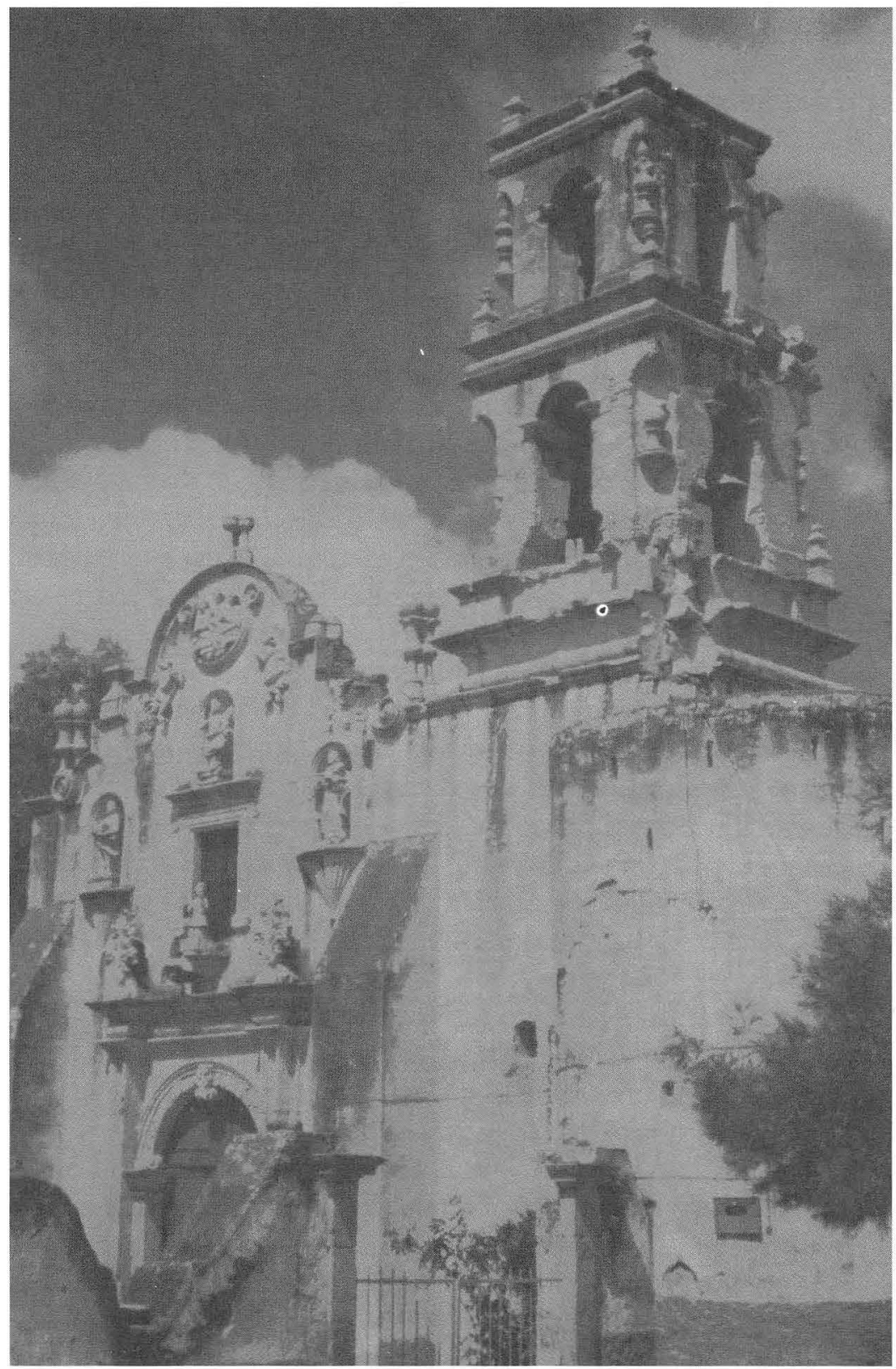

Fachada del templo de San Nicolás; El Nigromante, Pinos Zacatecas.
C A L
E I
D
O S
C O P I O 
miembros de los García Rojas, familia que fue propietaria de la hacienda desde finales del siglo XVIII y hasta la tercera década del XX. Contigua al coro, en el muro norte, se levanta una torre de dos cuerpos cuyo cupulín fue destruido por un rayo entre 1935 y 1940 y que hoy está restaurado; su ingreso es desde el atrio, que tiene forma casi cuadrada y que está delimitado por una barda mixtilínea cuyos parapetos contienen pequeños nichos, en uno de los cuales se advierte la imagen de la Virgen de Guadalupe, labrada toscamente en cantera. La portada del edificio da al este, pero no se corresponde con la orientación litúrgica de los templos cristianos, cuyo presbiterio daba al oriente, mientras que la portada daba cara al poniente; aquí la fachada está orientada precisamente a la inversa.

Esta última presenta una estructura planiforme sin diferenciación de sus cuerpos ni de sus calles que tan sólo están sugeridos en el aplanado por la escultura incrustada en el muro. La disposición de las imágenes en el conjunto sugeriría tres calles, de las que las extremas estarían definidas por sendos con las imágenes nichos de San Juan Bautista y San Antonio de Padua, mientras que la calle central -que marca el eje de composición de la fachada- por la puerta, la ventana del coro, un nicho con la imagen de San Miguel Arcángel, la imagen de una trinidad antropomorfa y la del patrón San Nicolás. Tanto la fachada principal como la antigua capillita, con sus respectivas torres, estaban policromadas con un fuerte pigmento rojizo que ahora es casi inapreciable, pero que debió haberle dado un aspecto único a la fachada, al grado de hacerla muy visible desde lejos y muy contrastante con el paisaje serrano.

La organización general de los elementos arquitectónicos en la portada confiere a la fachada un singular y se diría que ingenuo encanto, reforzado por el trabajo escultórico de las imágenes de bulto, de una talla no muy refinada pero con un modelado redondo, cuyas pequeñas dimensiones acentúan su apariencia "infantil"; quizá por ello la gente del pueblo acostumbra a llamar a la imagen principal, delante de la ventana del coro, con el diminutivo "San Nicolasito", que en este caso aparece como penitente, reconociéndose por estar hincado y por la posición de sus manos (vacías), que sugerirían estar asiendo los flagelos de la penitencia; otra posibilidad es que su mano diestra sujetase una cruz (que también es parte de su iconografía) y que de su siniestra, 
que aparece extendida junto con su brazo, volase un ave que es asimismo propia de sus atributos. De éstos, también se reconoce su hábito agustino, aunque la imagen aparece con el torso desnudo, así como la tonsura y la expresión de su cara, joven e imberbe.

Colindando con la torre, pero formando parte de las edificaciones del casco de la hacienda, se encuentra un bastión o garitón de sección semicircular para la defensa del conjunto, en caso de ataque, lo cual queda demostrado por las troneras que presenta, por donde los defensores podían disparar a los atacantes, posiblemente bandoleros.

Las dimensiones totales externas del edificio ( 7.40 metros del ancho de la nave, sin considerar el crucero, por 29.00 metros de largo) dan una relación proporcional igual a 1/3.91, que se acerca a la relación 1/ 4, la más común entre los edificios religiosos de una nave sin crucero del siglo XVI, ${ }^{32}$ aunque esta proporción daba una planta muy pequeña en los templos en forma de cruz, cosa que parece ajustarse a las condiciones y necesidades del templo de San Nicolás. El interior tiene una anchura de 5.46 por 7.80 metros de alto, hasta la bóveda de cañón, lo que da una proporción de 1:1.42, cercana también a algunas de las registradas en templos del siglo XVI. De hecho, esta proporción corresponde prácticamente a la razón inconmensurable $1: \sqrt{2}$, base del sistema ad quadratum, que tiene implicaciones en todo el diseño del recinto, y de manera particular en la portada, como se verá más adelante. La altura total desde el nivel de piso de la nave hasta la parte inferior de la linternilla (por tanto, la parte interior de la cúpula) es de 12.83 por aproximadamente 5.30 metros de ancho de la sección del crucero, lo que da una proporción de 1:2.42, proporción que corresponde de hecho a la razón inconmensurable $1: \theta$, relacionada con la anterior. Semejantes medidas lineales nos revelan un templo de relativamente pequeñas dimensiones, con un marcado acento no monumental dado su carácter doméstico, esto es, de templo devocional para la familia Quijas y los trabajadores de su hacienda, y ofrecen una pista del tipo de relaciones matemáticas subyacentes.

32 Cfr. George Kubler, Arquitectura Mexicana del siglo XVI, primera reimpresión, México, FCE, 1984, pp. 254-255.
C
A L
E
D
o
$S \quad C$
C
P I O 
Hasta el momento no he logrado encontrar documento alguno que señale la fecha exacta del inicio de la construcción del templo, aunque Aurelio de los Reyes afirma que fue hacia 1785, a raíz de un legado que dejó Francisca García de Roxas "para una finca de Señor San Nicolás", 33 atribución que no me parece del todo segura, ${ }^{34}$ pues un legado similar hizo Don José de Quijas Escalante y Saldaña cuando al morir, en 1677, dejó limosna para cuando se hiciere el templo parroquial de Pinos, y no por ello debe atribuírsele el mecenazgo de esa monumental obra. Me inclino a creer que el diseño corrió a cargo de un experimentado alarife o de un arquitecto docto en el trazado armónico de los edificios -por las razones que más adelante expondré- y que en su construcción se utilizó mano de obra de la región, aprovechando el continuo vaivén de maestros entre los reales de minas de San Luis Potosí, Pinos, Zacatecas y Durango, ${ }^{35}$ pues San Nicolás quedaba precisamente en la zona por donde pudo haberse dado una de las rutas del flujo de maestros entre los minerales de San Luis Potosí y Zacatecas. Entretanto, no puedo más que especular sobre quiénes fueron sus constructores, que por ahora permanecerán anónimos. Tampoco he podido detectar referencia alguna sobre el Libro de Fábrica y es muy posible que éste haya

33 A. de los Reyes, op. cit., p. 106.

34 Alfaro Aguirre, en contraste, atribuye la construcción a los Quijas, pues afirma que el templo fue mandado levantar por José de Quijas Escalante y Flores a finales del siglo XVII, y éste, como se dijo, murió en 1710, una fecha muy anterior a aquella en que los García Rojas adquirieron la hacienda. De hecho opina que el templo pertenece al "clasicismo tardío", "con una influencia mínima del barroco"; Según este autor, hacia 1731, tras la muerte de dos religiosos de la familia, "se colocaron [...], para conmemorarles -como era muy típico para ese tiempo- las imágenes de San Juan Bautista [...], San Antonio de Padua [...] [y] la imagen semidesnuda de San Nicolás de Tolentino...", lo que sugeriría que para entonces estaría terminada la obra; Cfr. "La arquitectura de las haciendas...", op. cit., p. 136 y pp. 144 y 158- 159. Clara Bargellini ha documentado bien este tránsito continuo en su libro La Arquitectura de la Plata. Iglesias monumentales del centro-norte de México, 1640-1750, México, IEE-UNAM, 1991, p. 73, en donde afirma que pasada la segunda década del siglo XVIII, los movimientos de maestros se produjeron de un poblado a otro y ya no desde fuera hacia adentro de la región centro-norte. No es descabellado suponer que San Nicolás de Quijas haya participado directa o indirectamente de este fenómeno si tomamos en cuenta que Bargellini considera a Pinos y su templo 
desaparecido o bien que se halle revuelto entre miles de papeles de archivos inéditos o privados de los descendientes de los Quijas.

Podemos darnos una idea al menos de la época de la dedicación del templo gracias a dos inscripciones existentes en sendas piezas de cantera: en la pila bautismal citada anteriormente, que estaba en la capilla adosada al muro norte de la nave principal, con la fecha en el pedestal que dice "1795", y en la piedra que sirve de base a la imagen de San Nicolás, colocada sobre la peana central de la fachada de acceso, con un texto semiborrado por la cantera devastada, que señala: "se isieron estos santos el a. de 9... [?]" (parece decir 1793, de acuerdo con una inspección ocular reciente). Ello apuntalaría la idea de que las imágenes efectivamente son dieciochescas; en cambio, puede asumirse provisionalmente que el templo, por sus características estilísticoarquitectónicas, es una obra construida entre finales del siglo XVII y principios del siglo XVIII.

Es un hecho demostrado, obligado además por las necesidades y los recursos de la época, que los establecimientos religiosos tardaban

parroquial como uno de los eslabones de la serie de iglesias monumentales del centro-norte, y si también ponderamos que San Nicolás queda realmente muy cerca del mineral pinense. Por ello no es improbable que en los procesos constructivos de muchos recintos comarcales (el analizado aquí incluido) hayan participado los "canteros de San Nicolás" y los del cercano Bernalejo. Por otro lado, como Bargellini lo prueba, hay evidencia de que uno de los Quijas, José de Ouijas Escalante y Flores, estaba muy atento a la actividad constructiva que se estaba registrando en Pinos, pues mandó edificar, por donación testamentaria, una pequeña capilla en el templo parroquial y hasta dejó fondos para un retablo, lo que necesariamente debió obligarlo a él o a sus albaceas (sus hermanos) a entablar trato con los maestros alarifes. Ver p. 231. De ahí que, poco antes de 1710, fecha de la muerte de José, debieron haber comenzado las relaciones de éste (o de sus parientes clérigos) con los maestros; 0 , después de ese año, las de sus descendientes con otros alarifes. Es igualmente significativa la huella, en buen número de recintos religiosos que van desde el desierto potosino hasta el semidesértico sur zacatecano, de San Antonio (patrón de los albañiles, arquitectos y picapedreros) y de San Nicolás, cuya proliferación se asocia no sólo con cultos particulares de los hacendados, sino también con la penetración de algunas misiones agustinas por la comarca, como lo prueba la existencia de una hacienda (la de Santa Cruz) propiedad de los "Reverendos Padres del Señor San Augustín", que estaba contigua a la de San Nicolás de Quijas. 
muchos años en construirse, sufriendo en el transcurso del tiempo modificaciones a su programa original y superponiéndose o yuxtaponiéndose diferentes codificaciones estilísticas. En este caso, no hay que olvidar que tenemos ya referencia documental de una antigua capilla desde el año de 1677, que, como dije, corresponde a la capillita adosada al muro norte del templo. Éste, sin embargo, tal como hoy lo conocemos, debió haberse comenzado a construir en su estructura básica poco después (¿qué tanto?, no lo sé) de la muerte de José de Quijas Escalante y Flores (que ocurrió como dije el 22 de junio de 1710), habiéndose quizá concluido hacia el primer tercio del siglo XVIII.

Cualquiera que haya sido el lapso de su construcción, lo cierto es que, por el contexto temporal, nos encontramos ante un monumento levantado dentro del horizonte barroco, aunque en el tránsito a él; por el contexto geográfico, podríamos ubicarlo, siguiendo a Vargas Lugo, dentro del barroco potosino y zacatecano. ${ }^{36}$ Lo que es incuestionable es que el monumento es de un moderado barroquismo: basta observar la conformación y el contexto de la fachada para advertir, según Wright, la presencia de "pilastras clasicistas, apoyando un entablamento, para enmarcar el arco de la entrada, cuya clave se destaca", ${ }^{37}$ lo que puede detectarse con toda claridad en la portada.

Como quiera que fuere la cosa, propuse que el templo presentaba propiedades armónicas "ocultas" tras el sobrio barroquismo de los elementos arquitectónicos y tras el ingenuo encanto de su iconografía, que finalmente el análisis reveló. ${ }^{38}$

Cfr. Elisa Vargas Lugo, Las portadas religiosas de México, México, IEE-UNAM, 1969, p. 327.

37 Ver David Wright, "Las modalidades en los Templos Barrocos Novohispanos", en Revista Mexicana de Arquitectura y Restauración, año I, núm. 1, Il semestre de 1991, p. 31 (cursivas mías). Esta afirmación me permite establecer una relativa equivalencia entre el "clasicismo tardío" del que habla Alfaro y el moderado barroquismo que adopto para la filiación estilística del templo.

38 Un examen preliminar de la portada, realizado en campo durante 1990, permitió descubrir algunas propiedades armónicas que sugerían la posibilidad de una estructura o sistema de relaciones proporcionales de más honda significación. 
Respecto a su patrimonio mueble, sólo subsiste una parte del antiguo acervo de imágenes de la iglesia de San Nicolás. ${ }^{39}$ La iconografía más antigua es un lienzo o "mural de ánimas", de aproximadamente 2.50 metros de ancho por 3.50 metros de alto, que se encuentra actualmente en la antesacristía del templo y que presenta un estado relativamente avanzado de deterioro, sobre todo en la base. Se desconoce el autor. En la esquina inferior izquierda del lienzo aparece una inscripción que reza así: "A devoción del Capitán Don Antonio Anselmo de Quijas Escalante y de su ... (frase ilegible)". Por otros documentos se sabe que la leyenda termina así: "... esposa Doña Ana María del Río Tirado, año de 1712".40

El lienzo muestra la imagen de la Virgen del Carmen en el eje de la composición. A su lado derecho se ve a San Nicolás de Tolentino, titular del templo, y a su izquierda a San Lorenzo, el diácono mártir. En su parte superior, coronando el mural, está la Santísima Trinidad, y en una posición un poco más baja, a ambos lados de esta última, se ve a San José con el niño en brazos y a San Antonio de Padua, también cargando al niño Jesús. En la parte inferior del mural se observan varias imágenes de las ánimas del purgatorio. La iconografía de la Virgen del Carmen la revela como intercesora de los pecadores ante Cristo. A San Nicolás de Tolentino, como abogado de las almas del purgatorio, se le ve alargando la mano hacia ellas (posiblemente asiendo el cinto que indica su iconografía), para salvarlas de las llamas.

La imagen principal del patrón de la hacienda, dentro del recinto religioso, se sitúa en el nicho mayor del altar neoclásico (no sé si tuvo retablo de madera); la acompañan las imágenes de la Virgen María, a la derecha, y San José a la izquierda; una pequeña imagen de la Guadalupana corona el altar. La capillita adosada, probablemente dedicada a San Nicolás ya desde esa época, hoy lo está a la Virgen del Rosario. En el centro del espacio se disponía, como se dijo, una pila

\footnotetext{
39 Cfr. M. Alejandro Sifuentes, "El Templo de la Hacienda de San Nicolás. Ex-Hacienda de San Nicolás de Quijas, Mpio. de Pinos, Zac. Aproximación a un análisis iconográfico", Curso de Iconología de la Arquitectura Colonial, inédito, Morelia, Mich., 1990.

40 Acosta Gómez, Miscelánea..., op. cit., p. 51.
}

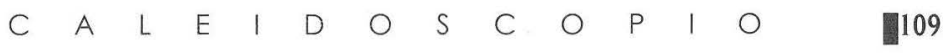


bautismal barroca de mediana factura y peores condiciones de conservación, fechada en 1795. En uno de los nichos de la barda mixtilínea del atrio está incrustada una imagen a la que ya cité previamente: la Guadalupana, a la que don José de Quijas Escalante y Flores veneró, pues en su testamento, leído al ser enterrado en su hacienda de San Nicolás el 22 de junio de 1710, mandó que se construyera una capilla "...en la parroquia de este Real, en donde se ponga un retablo y se coloque en él la imagen de mi señora de Guadalupe y una lámpara y seis blandones de plata para el adorno de dicha capilla". ${ }^{41}$ Otro tanto hizo don José su padre, quien al morir en San Nicolás el 6 de enero de 1677, dejó cien pesos de limosna para "...cuando se haga la Iglesia parroquial de Sierra de Pinos". ${ }^{42}$ Por último, el acervo se completa con el escudo de armas de Pedro de Quijas Escalante y Boroto.

La portada del templo presenta un prodigio de relaciones armónicas y sus imágenes sí parecen ser las originales, por su factura, modelado y parecido estilístico con las de la parroquia de Pinos. Desconozco a los artífices, pero se habla de la existencia de ciertos "canteros de San Nicolás", ${ }^{43}$ lo que delata que existió una tradición constructiva o artesanal y que es probable que algunos de sus miembros hayan intervenido en el trabajo de cantería.

En el mural de ánimas y en la portada de la iglesia se pueden reconocer las principales devociones de los Quijas Escalante, pues presentan las imágenes protectoras de la saga familiar, a saber: San José, que además de ser patrón de toda la Nueva España desde el siglo XVI, fue declarado patrón de los mineros en el norte, lo que me hace pensar en la posibilidad de que Pedro de Quijas Escalante y Boroto fuese también minero o que estuviera relacionado de algún modo con la minería, en particular con el real de minas de San Nicolás de los Ángeles (también bajo el patronato del eremita de la ciudad de Tolentino), un lugar muy cercano a El Lobo; además,

\footnotetext{
${ }^{41}$ APP, Libro de Entierros, n. 2, f. 18. La devoción a la Guadalupana es una prueba de que era español novohispano, como sus tíos y su propio padre (cursivas mías). APP, Libro de Entierros, n. 1, f. 81.

Acosta Gómez, Los Templos..., op. cit., p. 27.
} 
San José simbolizaría precisamente el solar paterno, ${ }^{44}$ la "hacienda madre", la de San José Agua del Lobo. San Nicolás, patrón de la hacienda y del templo analizado, abogado de los penitentes, confesor, "guía de almas" y protector de la Iglesia. San Antonio de Padua, patrón del agua en la alcaldía mayor de Sierra de Pinos, ${ }^{45}$ cuya devoción fue obligada por las condiciones de la región, particularmente en tiempo de secas, franciscano como algunos de los hijos y otros descendientes de Pedro. Y San Juan Bautista, relacionado con el bautismo y por tanto, nuevamente, con el agua. Devociones que, o ya profesaba don Pedro desde su natal Laredo en España, o él y su descendencia se vieron impelidos a hacerlo ante las precarias condiciones del medio en el que aquél sentó sus reales.

De esta estructuración se deduce que las principales razones que motivaron el tema iconológico de la portada y el mural de ánimas, se relacionan con devociones particulares que se invocaban para la protección de los habitantes de la hacienda contra las adversidades del medio, ${ }^{46}$ pues aparecen las temáticas de penitencia

44 Lo que sería congruente con el carácter de San José como patrón de los padres de familia, que "... le miran para aprender a agradar a Dios ante tanto desvío [... para gobernar con mano firme el timón de la barca de su casa y poder acertar a llevarla a buen puerto cuando la ven tan bamboleada por vientos racheados que presagian zozobra...": Cfr. "http://www.archimadrid.es/princi/princip/otros/santoral/prin/meses/mar/mar2.htm" (cursivas mías).

Declarado como tal a principios del siglo XVIII, a raíz de la sequía que azotó a Pinos en el primer tercio del siglo XVII. A este respecto, ver Acosta Gómez, Los Templos..., op. cit., p. 36.

Se me ha objetado recientemente que las imágenes no pueden ser consideradas mágicas o como conjuros contra los pecados y vicisitudes de la vida, como lo había planteado yo originalmente, a menos que esto se hiciera en el contexto de una población indígena actual. Baste recordar a mis críticos que ya desde el siglo XVIII el Diccionario de Autoridades (1726-1739) distinguía dos tipos de conjuros: los identificados con palabras supersticiosas y diabólicas; y los utilizados por los sacerdotes para "exorcizar "endemoniados" e invocar "nubes, tempestades", etc.", que estaban por tanto autorizados por la Iglesia; a este respecto, ver Oraciones, ensalmos y conjuros mágicos del Archivo Inquisitorial de la Nueva España, edición anotada y estudio preliminar de Araceli Campos Moreno, México, El Colegio de México, 1999, p. 38 (las cursivas son mías).

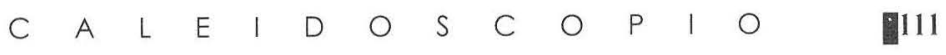


(San Nicolás), privación o mediación (San Juan Bautista, la vox clamantis in deserto y al que se le asocia con la magia desde tiempos remotos), ${ }^{47}$ sufrimiento o martirio (San Lorenzo), caridad (San Antonio de Padua), protección (San José, la Virgen de Guadalupe) intercesión (San Miguel, la Virgen del Carmen, el mismo San Nicolás y los ángeles), y salvación (la Trinidad). Diríase que la portada constituía una verdad revelada: ésa que indica el camino de la salvación después de atravesar múltiples infortunios en la vida; es decir, como si con la portada se quisiese recordar perennemente a los penitentes (o pecadores) la transitoriedad de la existencia o lo inerme que el plan divino hizo a la humanidad, al someterla a los rigores de la naturaleza, idea que en un primer análisis pareciera apuntar hacia el fomento de las devociones para contrarrestar, mediante su culto apropiado, lo precario de las condiciones del clima y del terreno. En cualquier caso, en la iconografía del templo se conjugaron devociones ibéricas y novohispanas, pues algunas imágenes aluden a añejos patronazgos medievales (San José como patrono de la Iglesia Universal y de los moribundos; La Virgen del Carmen como patrona de la marina española), y otras, si bien de origen medieval, habrían motivado cultos relacionados con las condiciones específicas del virreinato y sus amplias regiones, repletas de "gentiles" o "simples" (San Nicolás como "vencedor del pueblo" en sentido simbólico, o como "santo milagrero y popular" que con su "generosidad" conquistó los afectos y la fe del pueblo); o, en fin, con las características de sus habitantes que, además, se revelaron muy buenos canteros y constructores, como lo prueba la construcción del templo de San Nicolás.

\section{El análisis armónico de la portada del templo y sus resultados}

Al iniciar esta investigación planteé como hipótesis central que tras la estructura suprarracional, dada por el simbolismo religioso, existía un orden racional dado por las regularidades armónicas de la portada

47 Según esto, "... se dice que su voz, revelando las verdades del cristianismo, fue escuchada en los lugares más recónditos del desierto", de acuerdo con Englebert, citado en Ibid., p. 97. 
como un todo y en sus partes, es decir, que la configuración expresivoformal de la portada del templo de San Nicolás (la ordenación y la disposición aparente, visual, de los elementos arquitectónicos e iconográficos en el espacio), obedecía a la aplicación de sistemas de proporcionamiento armónico por parte de sus constructores. En particular, de acuerdo a lo dicho anteriormente, se perfilaba el empleo de los números $\sqrt{ } 2$ y $\theta$ y, por consecuencia, la presencia del sistema ad quadratum, como se verá más adelante. Para verificar la hipótesis, sometí a prueba aquel elemento con el objeto de descubrir las probables regularidades armónicas del todo y de sus partes, que suponía estaban detrás de la estructura suprarracional susodicha. Para ello empleé un método práctico, ${ }^{48}$ consistente en la revisión de la portada bajo cuatro grandes procedimientos de proporcionamiento armónico (la simetría dinámica de Hambidge, la sección áurea, los métodos de Moessel y de Lund) basados en el uso del compás y las escuadras de $45^{\circ}$ y $30 / 60^{\circ}$.

Las conclusiones particulares del análisis gráfico son las siguientes. En relación a la hipótesis central, el análisis efectuado demostró que efectivamente existe una regularidad armónica en la composición de la portada, revelada por el uso de razones basadas en diversos números irracionales que se presentan simultáneamente y con carácter no excluyente. En dicha regularidad demostraron tener un papel central las razones de tipo inconmensurable, más que las conmensurables. En el análisis de las partes de la portada, y en ésta como un todo, detecté formas semejantes repetidas en diversa proporción armónica, lo que demuestra a su vez que la portada presenta una economía de formas y por tanto un conjunto de relaciones de proporción matemática, cuyo fundamento son las progresiones geométricas. Los rectángulos áureos (o rectángulos $\varphi$ ), los rectángulos $\sqrt{2}$, los rectángulos $\theta$, y por ende los números $\varphi$ y $\theta$ (descubiertos gracias a la aplicación, en la fachada, de la simetría dinámica de Hambidge mediante procedimientos puramente geométricos, esto es, prácticos, que era la manera en que diseñaban los constructores antiguos), 
revelaron ser altamente significativos en la composición de la portada, lo que prueba el uso de progresiones dobles y la existencia de un sistema de armonía inconmensurable.

ESOUEMA 1

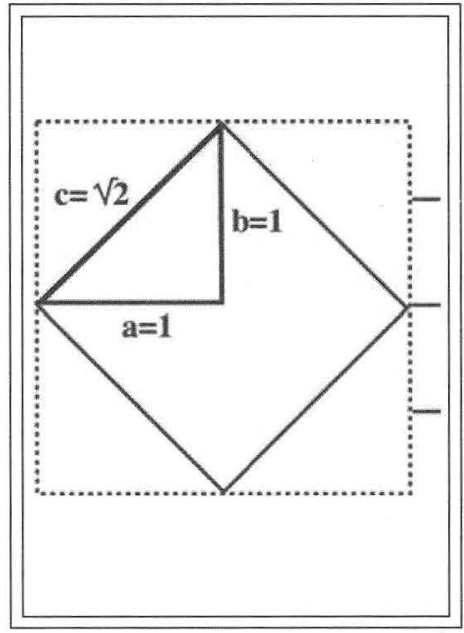

Sistema ad quadratum

\section{ESOUEMA 2}

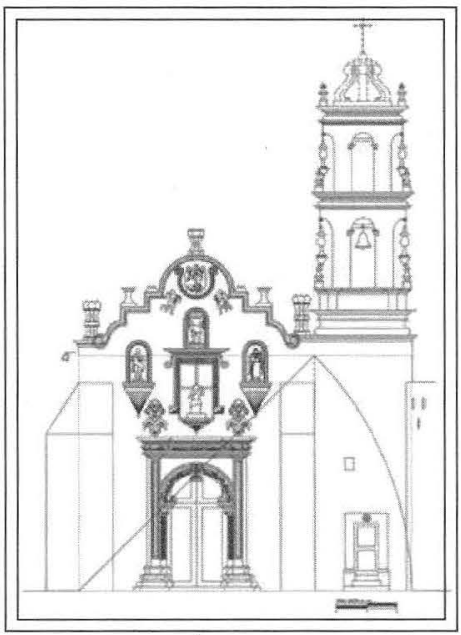

Rectángulo $\sqrt{ } 2$ sobre la fachada

En particular, se verificó el empleo del sistema de proporción denominado ad quadratum, con el que probablemente diseñó el arquitecto, ya que, de hecho, los rectángulos semejantes $\sqrt{2}$ y $\theta,{ }^{49}$ detectados en la portada, no son más que elementos constitutivos de ese sistema, puesto que $\theta=1+\sqrt{2}$, y puesto que, a su vez, $\sqrt{ } 2$ está asociado con la proporción $1: 1: \sqrt{2}$, obtenida de las relaciones entre los lados de un triángulo isósceles con dos lados iguales, cuya hipotenusa es la diagonal que los une, formando así un cuadrado

Recuérdese que ya me había referido a estos números anteriormente, a propósito de las relaciones proporcionales entre la base y la altura interior del templo hasta las bóvedas (1/1.42), y entre la base y la altura intcrior de la cúpula (1/2.42). Los divisores de estas razones corresponden prácticamente al valor de $\sqrt{2}$ (igual a $1.4142 \ldots$ ) y al valor de $\theta$ (igual a $2.4142 \ldots$ ). 
partido precisamente por la diagonal. Según afirma Platón en el Timeo, el triángulo isósceles de proporciones $1: 1: \sqrt{2}$ es uno de los dos más bellos y perfectos triángulos (el otro es el escaleno, de proporción $1: 2: \sqrt{3}$, que fue el más utilizado en el diseño de las catedrales góticas), con los cuales estaban conformados los sólidos platónicos, responsables de toda la estructura de la materia y del cosmos. ${ }^{50}$ Las proporciones de los sistemas ad quadratum $(1: 1: \sqrt{ } 2)$ y ad triangulum $(1: 2: \sqrt{ } 3)$ fueron pues concebidas ya desde la antigüedad clásica griega por Pitágoras y Eudoxo, aunque el sistema como tal fue codificado en la Edad Media a partir de la escuela catedralicia de Chartres. Es muy probable que fuera conocido por los constructores barrocos novohispanos, a juzgar por diversas evidencias que he ido recogiendo al analizar varios monumentos de este período, ${ }^{51}$ y a juzgar también por el hecho de que dicho sistema formara parte de los conocimientos casi herméticos - cuando menos místicos acerca de la belleza de las formas, problemática que siguió permeando, en su versión aristotélica, en el pensamiento escolástico de los siglos XVII y XVIII en Nueva España. Por otro lado, el número de oro, también encontrado en la portada del templo, era demasiado célebre (incluso en el período barroco) como para desestimar su empleo.

50 Ver a este respecto Michael Bispham, "Platonic Geometric Atomism in Medieval Design", en "http://fupro.com/plat/index.htm".

5. Nuestro estudio del Camarín de la Inmaculada en el Templo de San Diego, en Aguascalientes, demuestra que en su geometría simbólica, concebida en un plan octagénico y dinérgico, basado en el octágono regular y el octágono estrellado, está presente también el sistema ad quadratum, pues el segundo de los octágonos establece relaciones proporcionales, entre sus diversos segmentos constitutivos, que están relacionados con los números irracionales $\sqrt{2}$ y $\theta$. Ver Sifuentes, García y Martín del Campo, El Camarín... op. cit., pp. 107-115, especialmente la p. 108. Ver también el estudio inédito de Libertad Zamudio Bernal y Marco Antonio Delgado Peralta, "El Templo del Señor del Encino. Los valores armónicos e iconográficos de su portada", que llega a resultados muy similares (se prepara actualmente una publicación de este trabajo). 


\section{ESOUEMA 3}

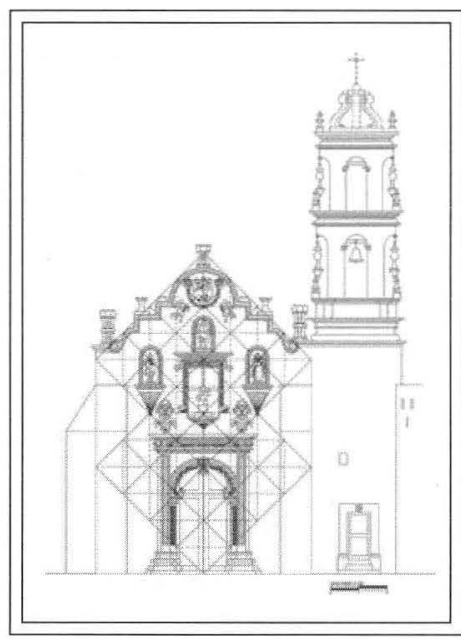

Sistema ad quadratum sobre la

fachada

Así pues, el análisis corroboró que existe una estructura racional (basada en proporciones inconmensurables) que rige la composición de la portada, pero que no era visible directamente sino a través de su revestimiento simbólico y religioso. El carácter "irracional" de las proporciones empleadas, así, aparecía como más apropiado a los valores católicos vigentes en el período novohispano, pues estos sistemas representarían, en las claves de significado del mundo religioso barroco, aquello que está más allá de la razón humana, lo que no tiene medida ni fin: la divinidad; de ahí la sobrevaloración religiosa de su significado matemático; de ahí también esta suerte de "inversión de la realidad", que es la problemática marxista de la falsa conciencia.

\section{Discusión}

Sobre la base de los anteriores resultados, y por diversas evidencias que he ido recogiendo a lo largo de los años, me atrevo a pensar que a nivel arquitectónico se observan ciertas 
regularidades en los procesos de producción de la arquitectura religiosa de la región de Pinos, cuyos recintos comparten desde luego, como primera característica, su condición de templos no monumentales, exceptuando, claro está, la parroquia de San Matías de Sierra de Pinos, investigada por Clara Bargellini; como segunda característica, su ubicación en antiguas haciendas; como tercera característica, la relativa regularidad de sus procedimientos técnicos (materiales de construcción, técnicas constructivas) $)^{52}$ y la huella de cierto grupo de maestros y alarifes que probablemente se movían de un pueblo a otro, confiriéndole a la mano de obra ciertos rasgos también comunes; y como cuarta característica, la presencia sistemática de ciertas imágenes en las portadas de los templos, cuya significación iconográfica induce a relacionarlas con las condiciones climáticas de la región y con la penuria de agua (específicamente con la representación, en varias capillas, de San Antonio de Padua, patrón del agua, santo cuyo culto era esencial para atraer la lluvia al semidesierto pinense), o bien con aspectos sociales e históricos más profundos. La presencia de San Antonio de Padua, famoso por sus poderes taumatúrgicos y cuya fiesta del 13 de junio marcaba simbólicamente el inicio de la temporada de lluvias -imagen que por cierto aparece tanto en la portada del tempo de San Nicolás como en la antigua hacienda de San José Agua del Lobo y en otros templos no monumentales de la región-, atestigua algo más que meras coincidencias. Asimismo, la presencia de la imagen de la Inmaculada Concepción (patrona de España y de la infantería española) en otros tantos recintos religiosos de la zona, obliga a pensar en las devociones fomentadas por los franciscanos que se introdujeron desde finales del siglo XVI en la comarca (no en balde el primer patronímico del lugar fue "Real de Minas de Nuestra Señora de la Concepción de Sierra de Pinos");

52 El trabajo de Alfaro Aguirre es muy rico en el análisis de este punto. Este autor, por cierto, supone que la mano de obra que se abocó a la construcción del templo de San Nicolás provino del barrio de Tlaxcalita en Pinos; "... sin embargo [dice], parece más probable que la mayoría de los trabajadores fueran contratados en Michoacán y en el centro del virreinato", en donde abundaba; op. cit., p. 143.

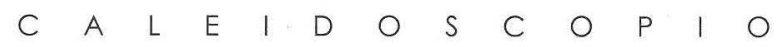


la presencia también de Juan el Bautista es significativa, pues su fiesta del 24 de junio (coincidiendo prácticamente con el solsticio de verano), consagra para la región el ciclo pluvial (aunque por otro lado es protector contra las granizadas): ${ }^{53}$ es de notarse también la imagen de San Miguel Arcángel como intermediario entre Dios y los seres humanos. Ejemplos todos a los que la preceptiva cristiana les otorgaba la función de imágenes intercesoras o que mediaban entre la humanidad y la divinidad para, en unos casos, atraer los beneficios de la naturaleza (San Antonio de Padua), o de la propia divinidad en los otros (la Inmaculada, San Miguel Arcángel, y el abogado de los penitentes, San Nicolás de Tolentino).

En este sentido, propongo que a nivel del conjunto de templos no monumentales de la región, se produce, en consonancia con la axiomática cristiana, una transferencia de asociaciones que invierte las relaciones de causa-efecto, haciendo aparecer a los fenómenos naturales como consecuencia del culto. ${ }^{54}$ Este orden aparente opera para el analista como articulación, cuyo resultado es una armonía engendrada en las relaciones espaciales de la imaginería religiosa con las condiciones del medio ambiente, es decir, un conjunto de significados unitarios y armoniosos territorializados, por los cuales el orden suprarracional, ya geométricamente sacralizado para comunicarse, adopta contenidos topológicos para objetivarse.

Asimismo, en éste como en otros recintos se observa el empleo persistente y consistente, si bien no sabe todavía qué tan sistemático, de cierto tipo de relaciones armónicas y sistemas de proporcionamiento (sobre todo inconmensurables), cuyo

53 Araceli Campos afirma que la brujería también se relacionó con la fiesta de San Juan; ver Oraciones..., op . cit., p. 98. La circunstancia del nombre de El Nigromante, con el que se conoce a la comunidad rural que suplantó a la antigua hacienda de San Nicolás, y el hecho de que a sus habitantes se les conozca como "brujos", es poco más que una simple coincidencia.

54 Tomo lo expresión, acomodándola a mis propósitos, de Johanna Broda en su trabajo: "Arqueoastronomía y desarrollo de las ciencias en el México prehispánico", en Marco Arturo Moreno Corral, Historia de la astronomía en México, tercera edición México, SEP-FCE-CONACyT (Col. La Ciencia para Todos), 1998, p. 96. 
manejo por los diseñadores fue revestido por una capa de connotaciones simbólicas sagradas, lo que también produce una transferencia de asociaciones similar a la anterior, que invierte las relaciones de causa-efecto, haciendo aparecer el tratamiento de objetos racionales, esto es, los números y las proporciones (el orden racional), como determinado por contenidos y valores religiosos actualizados en el culto a los santos (el orden trascendente o suprarracional).

Diversas evidencias permiten afirmar provisionalmente que en el período barroco predominaron en el diseño de los recintos de culto los símbolos de tradición neoplatónica, debido a la todavía fuerte tradición escolástica entre los intelectuales, cuyos autores preferidos (San Agustín, Tomás de Aquino y otros escritores escolásticos) eran invocados con delectación y a través de los cuales es posible rastrear ecos lejanos del platonismo, aunque en clave aristotélica. El uso de proporciones inconmensurables en la arquitectura salvó el conflicto teológico entre la concepción de la materia que subsistía en el neoplatonismo, herética a los ojos de la Iglesia, y el modo como el tomismo aristotélico concibió el conocimiento de las cosas, dado que ambas visiones tuvieron como punto común dichas proporciones.

A este respecto, Parkinson afirma que la reforma luterana era agustiniana y platónica y que, en cambio, la contrarreforma católica era tomista y aristotélica; afirma también que esta última "...encontraba que la verdad y la belleza eran conmensurables, y [que] el naturalismo barroco llegó a ser un medio primario de llevar al espectador a un estado de comunión mística con lo divino". ${ }^{55}$ No puede negarse sin embargo que atrás del tomismo aristotélico estaba la huella del platonismo, a través de la perpetuación de la matemática pitagórica y, por extensión, de la teología agustiniana; baste recordar lo que de los números decía

55 A este respecto, ver Lois Parkinson, "Aproximaciones interartísticas a la lectura de textos verbales y visuales", en Esther Cohen (editora), Aproximaciones. Lecturas del texto, México, UNAM, 1995, pp. 175-177.

$\begin{array}{llllllllllllll}C & A & L & E & I & D & O & S & C & O & P & \text { I } & O & \end{array}$ 
San Agustín: "Así llegó la razón al reino de la vista, y buscando por cielo y tierra, percibió el placer por la belleza; y la belleza por las formas; y las formas por proporciones; y las proporciones por números". ${ }^{56}$ Creo que la conmensurabilidad que menciona Parkinson no debe tomarse en un sentido literal, matemático, pues yo sostengo precisamente lo contrario: el predominio de la inconmensurabilidad en el período barroco; pienso que lo que salva el punto, al menos en el campo arquitectónico, es la consideración de que más que "conmensurable", la belleza era geométricamente materializable, y que los números irracionales, simbolizados como pertenecientes a un orden divino, se hacían asequibles al entendimiento humano gracias precisamente a la geometría, ${ }^{57}$ dado que, como afirma Bispham, "un edificio diseñado geométricamente tiene, en última instancia, la potencialidad para una armonía inherente resultado del proceso que consiste en tomar sus proporciones de figuras geométricas simples [...]; hasta hace relativamente poco tiempo, la arquitectura era una ocupación cuantificada geométricamente, más bien que aritméticamente" ${ }^{58}$ Este último autor afirma que a causa de sus dificultades teológicas con el tomismo aristotélico, la doctrina atomista de la materia, debida a Platón, sobrevivió clandestinamente en los constructores y en los hombres de saber, incluso hasta el siglo XVII.

Si esto es así, cabría esperar que en el diseño de los templos prevaleciera, más incluso que la tradición euclidiana, el empleo de las matemáticas de tradición pitagórica, que se caracterizaba por cierto

Citado por Alberto Pérez Gómez, La génesis y superación del funcionalismo en arquitectura, México, Ed. Limusa, 1980, p. 39.

Quiero introducir aquí mi propia versión: planteo hipotéticamente que el eslabón que une la aparente contraposición del pensamiento pitagórico-platónico y por extensión agustiniano con el pensamiento aristotélico-tomista, lo constituyó, al menos en la arquitectura religiosa novohispana, una suerte de teoría implícita de la proporción a través del empleo de los números irracionales o inconmensurables, que, al someter a reglas armónicas a las imágenes, permitirían percibir (por experiencia visual y sensorial) la verdad y la belleza y conducir por ello a los fieles al conocimiento espiritual y a la comunión mística con lo divino. Ver Bispham, op. cit. 
manejo místico, por no decir esotérico, de los números y de las proporciones, ${ }^{59}$ como lo revela diáfanamente el pasaje del obispo de Hipona. En cualquier caso, el trazado armónico de los edificios barrocos era una práctica mucho más frecuente de lo que podría aparecer a simple vista, pues el revestimiento ornamental de las estructuras arquitectónicas impedía apreciar el orden racional detrás de las imágenes, y además el conocimiento que dicha práctica suponía era materia reservada sólo para iniciados, es decir, los constructores y los jerarcas eclesiales, de ahí su carácter más bien velado; y quizá habría que añadir que esa práctica parece más común de lo que los historiadores han supuesto.

Sin embargo, aquella inversión de la realidad no era consciente en los hombres de iglesia, ni en los constructores y los hacendados, mucho menos en los fieles pobres. El analista, sin embargo, debe reconocer que hay elementos de congruencia, considerada desde los propios presupuestos de la axiomática cristiana, tal como fue profesada en la Nueva España, observables en enunciados aceptados como universales (o que pueden aparecer como verdaderos, esto es, justificados: la prédica del amor, la caridad, el respeto, la tolerancia, la honradez, etc.), pero que fueron en realidad distorsionados por su irrecusable función de dominio, puesta de manifiesto en la aceptación (sin reparos) de otros enunciados que a su vez aparecían como si estuvieran plenamente justificados, a los ojos de la Iglesia y de la clase dominante (la guerra "justa" contra los infieles, la aceptación resignada del orden jerárquico vigente, la imposición de una nueva religión y nuevas modalidades de vida y la expoliación de los indígenas), operándose así la visión mistificada y por tanto invertida de la realidad.

De ahí que bajo la piedad barroca haya operado una ideología religiosa muy precisa, pues se presentó históricamente como cumpliendo una función real de enmascaramiento, asociada a la perpetuación de la dominación ideológica y del poder de clase de un grupo social y, recubriendo a ésta, realizando una función aparente de

\footnotetext{
59 Cfr. a este respecto René Taylor, Arquitectura y Magia. Consideraciones sobre la idea de El Escorial, segunda edición, Madrid, Ed. Siruela, 1995, p. 15.
} 52. 
cohesión social. ${ }^{60}$ Éste fue un fenómeno particularmente visible en la sociedad novohispana: para los sectores pudientes, la salvación se ganaba comprando indulgencias o donando obras pías; para las masas pobres, la salvación pasaba por aceptar la condición de pobreza a cambio de la esperanza de una vida mejor en el más allá. Y ambos aspectos valen también para los patrones y los peones de las haciendas mexicanas.

Como afirma Puente Ojea, la Iglesia Católica supo preservar la promesa de la vida más allá de la muerte bajo la premisa dual de conjugar retóricamente presente y futuro, esperanza pero a la vez resignación. La consecuencia obvia de dicha promesa resultó ser la "...creciente docilidad social, política y religiosa de la masa de creyentes". ${ }^{61}$ En las capillas de las haciendas dicha promesa encontró su justificación más apropiada a través de la admonición escatológica, que "invitaba" (léase condenaba) a peones y amos a aceptar resignadamente su destino, pues los programas iconográficos implicaban un mensaje en tal sentido, de otra manera sobrevendría el castigo divino: en esta vida, las penurias y rigores derivados de los elementos -como las sequías en Pinos-; en la otra, el infierno.

Por ello, los templos no monumentales de las antiguas haciendas de Sierra de Pinos jugaron un rol importante en la coacción económica y la retención de la mano de obra en aquellas unidades, una de cuyas vías fue de orden simbólico: la reproducción ideológica de actitudes y valores morales consonantes con las exigencias de dominación de los hacendados, gracias a la preceptiva cristiana que promovió de múltiples maneras (la didáctica visual de las portadas incluida) la promesa de ultratumba.

Los programas iconográficos de las portadas aluden a aquella admonición, pues en ellas se produce la inversión de causa-efecto entre el culto a los santos y los ciclos de la naturaleza, atribuyéndose

\footnotetext{
60

Estos últimos párrafos son un desarrollo, ajustado a mis propósitos, del libro de Luis Villoro, El concepto de ideología y otros ensayos, México, FCE, 1985, pp. 17 -

${ }_{61}$ A este respecto ver Gonzalo Puente Ojea, Ideología e historia. La formación del cristianismo como fenómeno ideológico, México, Siglo XXI, 1974.
} 
a los primeros (o al culto que propicia su "acción") el poder para propiciar la lluvia. Frente al problema de la evangelización y la perpetuación del culto católico entre una población (indios y mestizos) que no estaba en posesión del alfabeto, pero que sí estaba acostumbrada en cambio a los rituales a cielo abierto en espacios regidos por un "frontalismo esencial" (según González Galván), las portadas se convirtieron en el mejor recurso didáctico para la enseñanza de los preceptos cristianos; eran libros abiertos que mediante imágenes facilitaron transformar el dogma en símbolos creíbles que aparecían como obra de Dios (y por tanto plenamente justificados a los ojos de las masas de fieles... y de la Iglesia).

Derivado de todo lo anterior, sostengo la conformación de una geometría sacralizada y de una armonía topogénica ${ }^{62}$ en la arquitectura del semidesierto nororiental neogallego, que presumo tendrá repercusiones (a favor o en contra) en la manera de entender, en un plan más general y desde una perspectiva histórico-dialéctica, a la arquitectura religiosa novohispana como expresión de la relación entre una teoría de la proporción (a través de la matemática pitagórica, platónica y agustiniana) y las ideas escolásticas (a través del simbolismo religioso aristotélico-tomista), vigentes ambas en los siglos XVII y XVIII.

\section{Comentario final}

La reconstrucción del fenómeno en el pensamiento me ha llevado a descubrir primero cómo en la portada motivo del análisis se operó históricamente la relación entre el diseño y el simbolismo religioso y, segundo, cómo puede ser entendida teóricamente dicha relación. Lo anterior me permite proponer la siguiente formulación general:

La iconografía de las portadas de los templos barrocos cristianos

62 Entiendo por armonía topogénica la generación de reglas de composición en el espacio (o en el territorio, modalidad que denomino armonía topológica) basadas en sistemas de proporcionamiento a los que se somete la iconografía; entiendo por geometría sacralizada el revestimiento religioso de las estructuras racionales guiadas por sistemas de proporcionamiento, para hacerlas visibles (comunicables) a los devotos.

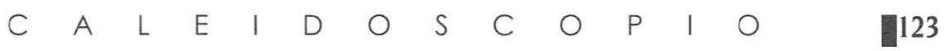


crea la apariencia de un orden supraterreno (suprarracional), inasequible al entendimiento humano, asequible a su corazón o a sus sentimientos, y por ello tomado como producto de un orden superior trascendente, divino, con el que se pretendía persuadir a la población autóctona de la vida recta (resignación en esta vida, esperanza en el cielo) y que era expresado a través de símbolos "creíbles". Este estudio ha revelado que el uso de razones armónicas en la composición de la portada del templo de San Nicolás, tanto en los elementos que la integran (elementos arquitectónicos e imágenes de culto) como en el conjunto mismo, es el que dota al monumento de un orden unitario, bello y armónico, reconocible por la proporción visual gracias a la repetición de formas semejantes pertenecientes a las mismas clases de relaciones proporcionales, que probablemente fue conocido y aplicado por sus constructores anónimos.

Esto me llevó a concluir que el "puente" que permite la articulación entre la arquitectura religiosa y la iconografía cristiana es precisamente la geometría, o más exactamente, el orden en la expresión formal dado por el uso y aplicación de razones armónicas y sistemas de proporcionamiento muy precisos. Es este orden el que regula armónicamente la organización iconográfica e iconogésica de las portadas, y no viceversa. Es decir, la geometría (la teoría de la proporción vigente, o los trazos de proporcionamiento como expresión del estatuto alcanzado por las fuerzas productivas en el campo del diseño) es un aspecto del control de la producción material de los monumentos que rige matemáticamente el programa iconográfico, aunque este último parezca fungir como el hilo conductor de la didáctica religiosa, creando la "apariencia" de ese orden trascendente cuya función de persuadir se presenta como justificada, a la luz de la preceptiva cristiana, cuando, en última instancia, su función objetiva es la de someter ideológicamente a los fieles, lo cual no demerita en modo alguno la belleza de estos recintos.

Desde el punto de vista de la puesta en discusión de estos resultados en un contexto teórico propio del materialismo histórico-dialéctico, sostengo que esa relación que para el analista opera en el nivel histórico concreto real como articulación sutil visible (o creíble) de lo racional y lo suprarracional (excitando los sentidos de los fieles), se trastoca en el nivel teórico abstracto en determinación del contenido de lo suprarracional (el 
simbolismo de la iconografía) por lo racional (la geometría, la armonía matemática), sin demérito de la relativa autonomía y el desarrollo propio de lo simbólico (autonomía relativa que se produce también en la forma y el contenido en los niveles teórico concreto e histórico concreto real, respectivamente). Simplemente, como dije, lo simbólico se objetiviza mediante lo racional en un monumento dado. Sin embargo, múltiples pruebas apuntan a que en una sociedad concreta, la novohispana, aquella articulación (puesta de relieve por el analista y percibida en cambio como un continuo visual indiferenciado por los fieles) aparece, a su vez, como relación de determinación del orden trascendente por sobre el orden racional (pues la forma de lo suprarracional se autonomiza absolutamente en el nivel histórico concreto aparente), debido a la necesidad de mantener el orden social vigente y la dominación de una clase por otra sobre la base de enunciados justificados a la luz del dogma cristiano (o que aparecen como si estuvieran justificados). ${ }^{63}$ El siguiente esquema sintetiza este aparente complejo sistema de relaciones:

en un orden histórico concreto real y en un orden histórico concreto

\section{ESOUEMA 4}

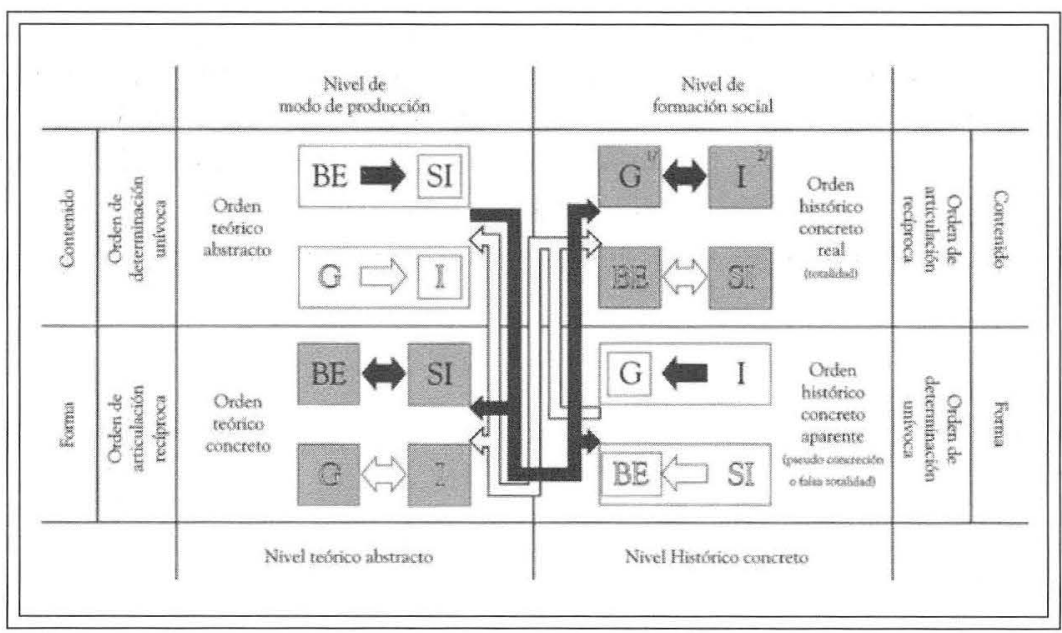

Relaciones entre base económica, superestructura ideológica, geometría e iconografía

63

Luis Villoro, op cit.

C A L E

E I

D

O S C

C O

P

O 
aparente; la observación del fenómeno comenzó por este último hasta alcanzar, sucesivamente, los siguientes niveles, tamizados cada vez por el pensamiento riguroso y científico. En cambio, el nivel teórico se desdobla en un orden teórico concreto y en un orden teórico abstracto; la reconstrucción explicativa comienza desde este último, para de esta manera, elevándose de lo más abstracto hasta lo más concreto, reconstituir, enriquecido por el pensamiento, el fenómeno real en su concreción histórica y develar con ello la apariencia inicial caótica (la pseudoconcreción o falsa totalidad).

La articulación que se produce en el nivel histórico concreto real implica que en la arquitectura religiosa novohispana el orden racional asume, para comunicarse, contenidos sagrados (formales, temáticos y topológicos), lo que llamo geometría sacralizada, y que a su vez el orden suprarracional necesita de contenidos matemáticos (geométricos y topogénicos) para objetivarse. El resultado es una armonía que se engendra en las relaciones espaciales de los elementos arquitectónicos e iconográficos, esto es, una armonía topogénica.

Como se ve, a partir del caso analizado pretendo abrir vías para construir un conocimiento general, una teoría de la arquitectura religiosa barroca novohispana bajo la cual subyacen procesos de producción, de pensamiento y de acción de individuos y grupos sociales concretos. Tómense estos resultados, parafraseando a García Canclini, como un cierre transitorio que pretende sin embargo una totalización argumentativa, que comparto aquí y que servirá para invitar a mis colegas a controvertir estos resultados y seguir discutiendo. ${ }^{64}$

*

${ }^{64}$ Néstor García Canclini, La globalización imaginada, primera reimpresión, México, Ed. Paidós, 2000, p. 16. 